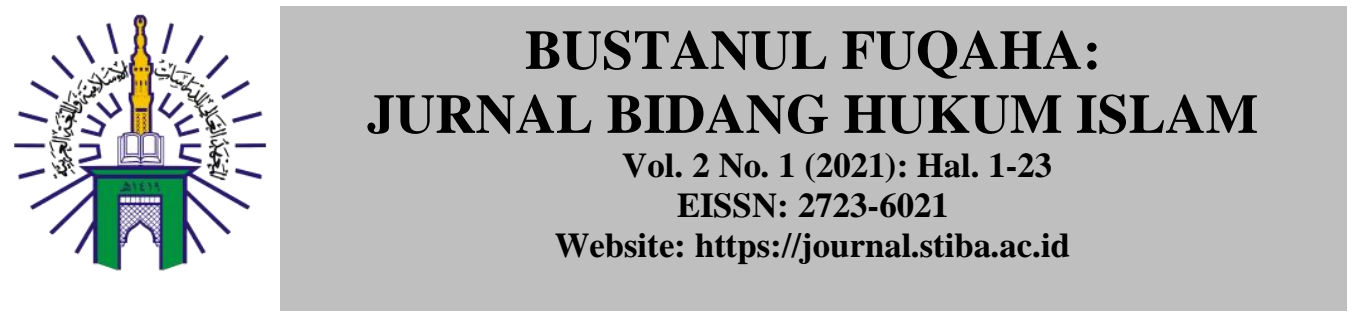

\title{
NIKAH DENGAN LAFAZ HIBAH (STUDI KOMPARATIF ANTARA JUMHUR ULAMA DAN IMAM ABU HANIFAH)
}

\section{MARRIED WITH LAFAZ HIBAH (COMPARATIVE STUDY BETWEEN MAJORITY SCHOLAR OF ISLAM AND PRIEST ABU HANIFAH)}

\author{
Muhammad Taufan Djafri \\ Sekolah Tinggi Ilmu Islam dan Bahasa Arab (STIBA) Makassar \\ muhtaufandjafri@stiba.ac.id \\ Islahuddin Ramadhan Mubarak \\ Sekolah Tinggi Ilmu Islam dan Bahasa Arab (STIBA) Makassar \\ islahuddin@stiba.ac.id \\ Vaizki M. Rusli \\ Sekolah Tinggi Ilmu Islam dan Bahasa Arab (STIBA) Makassar \\ vaizkimrusli@gmail.com
}

\begin{tabular}{ll}
\hline Keywords : & \multicolumn{1}{c}{ ABSTRACT } \\
\cline { 2 - 3 } $\begin{array}{l}\text { Jumhur Hanifah, Fiqh, Grants, } \\
\text { Marriage. }\end{array}$ & This study aims to determine and understand the law of marriage \\
with lafaz grants according to the jumhur of scholars and Imam Abu \\
Hanifah. In this study, the authors used a library research type using \\
a normative juridical approach and comparative analysis. The \\
research results found are as follows; First, a grant-based marriage \\
is not recommended according to the jumhur of scholars because the \\
number of scholars only allows lafaz of marriage with lafaz al-nikah \\
and al-tazwij as usual. Second, a marriage with a grant name may \\
be in the Imam Abu Hanifah mazhab because while it is still in the \\
form of ownership transfer, the name may be used in the \\
implementation of the marriage contract. So the use of lafaz grants \\
in a marriage contract is not allowed in the view of the jumhur of \\
scholars, but it is okay for anyone who wants to use Imam Abu \\
Hanifah's opinion about permitting to use the lafaz grant in a \\
marriage contract, because this is just a difference in fiqh issues that \\
sometimes the scholars differ in interpreting or understanding an \\
argument.
\end{tabular}




ulama hanya membolehkan lafaz nikah dengan lafaz al-nikah dan al-
tazwij sebagaimana biasanya. Kedua, Nikah dengan lafaz hibah
boleh dalam mazhab Imam Abu Hanifah karena selagi hal tersebut
masih dalam bentuk alih kepemilikan maka lafaz tersebut boleh
digunakan dalam pelaksanaan akad nikah. Jadi penggunaan lafaz
hibah dalam sebuah akad pernikahan tidak diperbolehkan dalam
pandangan jumhur ulama, namun tidak mengapa bagi siapa saja yang
ingin menggunakan pendapat Imam Abu Hanifah tentang bolehnya
menggunakan lafaz hibah dalam sebuah akad pernikahan, karena hal
ini hanyalah sebuah perbedaan dalam masalah fikih yang terkadang
para ulama berbeda dalam menafsirkan atau memahami sebuah dalil.

Diterima: 9 November 2020; Direvisi: 10 Januari 2021; Disetujui: 23 Maret 2021; Tersedia online: 23 April 2021.

How to cite: Djafri, Muhammad T., Ishlahuddin Ramadhan Mubarak and Vaizki M Rizki, "Nikah dengan Lafaz Hibah (Studi Komparatif Antara Jumhur Ulama dan Imam Abu Hanifah).” BUSTANUL FUQAHA: Jurnal Bidang Hukum Islam 2, No.1 (April 23, 2021): 1-23. doi: https://doi.org/10.36701/bustanul.v2i1.278

\section{PENDAHULUAN}

Pernikahan bagi umat manusia merupakan hal yang penting, karena dengan pernikahan seorang akan memperoleh keseimbangan hidup baik secara psikologis, sosial, maupun biologis. Pernikahan dalam Islam merupakan anjuran bagi kaum muslimin dan merupakan prosesi yang dibenarkan dalam syaria't dalam rangka pemenuhan kebutuhan bilogis manusia, serta sebagai sarana untuk mendapatkan rasa tentram dan tenang, serta keberkahan ${ }^{1}$.

Dalam Undang-undang No. 1. Tahun 1974 dinyatakan bahwa: "Perkawinan ialah ikatan lahir batin antara seorang wanita dan seorang pria sebagai suami istri dengan tujuan membentuk keluarga (rumah tangga) yang bahagia dan kekal berdasarkan ketuhanan Yang Maha Esa"2. Nabi Muhammad saw. juga menganjurkan kepada umatnya terutama kepada para pemudanya untuk menikah, agar dapat lebih menjaga pandangan dan kemaluan dari hal-hal yang tidak dianjurkan. Rasulullah shallahu 'alaihi wasallam bersabda yang artinya: "Barang siapa yang telah sanggup untuk menikah maka menikahlah!, sesungguhnya menikah dapat mencegah dari melihat sesuatu yang terlarang dan dapat membentengi farji (kemaluan), dan barangsiapa yang belum mampu (menikah)

\footnotetext{
${ }^{1}$ Wiwin Pranata dan Abdul Rahim. Penundaan Kehadiran Anak Akibat Perkawinan Usia Muda Ditinjau Menurut Hukum Islam (Studi pada Desa Jaling, Kecamatan Awangpone, Kabupaten. Bone). NUKHBATUL'ULUM: Jurnal Bidang Kajian Islam 4 no. 22 (2018), 173.

${ }^{2}$ Republik Indonesia, Undang-undang RI, Nomor 1 Tahun 1974, Tentang Perkawinan, (Bandung: Citra Umbara, 2007), 2.
} 


\section{BUSTANUL FUQAHA: \\ JURNAL BIDANG HUKUM ISLAM \\ Vol. 2 No. 1 (2021): Hal. 1-23 \\ EISSN: 2723-6021 \\ Website: https://journal.stiba.ac.id}

maka berpuasalah karena sesungguhnya puasa itu adalah penawar/penekan nafsu syahwat." (Hadis riwayat Al-Bukhari no. 1905) ${ }^{3}$.

Dalam membentuk keluarga yang sejahtera dan bahagia diperlukan pernikahan yang sah menurut agama dan tata aturan yang berlaku. Salah satu aturan yang dibutuhkan dalam pernikahan adalah ijab kabul yang merupakan salah satu rukun dalam akad nikah atau yang biasa disebut dengan sigat akad nikah. Mayoritas ulama setuju bahwa lafaz yang dapat digunakan dalam akad nikah haruslah terdiri dari lafaz yang terbentuk dari akar kata "al-nikāh" atau "al-tazwīj”. Hal ini berdasarkan atas nas yang tertera di dalam Al-Qur'an maupun hadis.

Pada dasarnya nikah sebagaimana akad-akad yang lain juga merupakan transaksi alih kepemilikan. Atas dasar inilah ada ulama yang menyatakan bahwa lafaz apapun selama masih mengandung unsur alih kepemilikan dan obyeknya adalah benda maka lafaz itu bisa digunakan dalam akad nikah, dan menyatakan bahwa nikah dengan menggunakan lafaz hibah hukumnya adalah sah, seperti perkataan wali sang mempelai wanita yang mengatakan kepada sang mempelai pria bahwa kami hibahkan putri kami kepada saudara fulan bin fulan dengan mahar yang telah disepakati tunai karna Allah. Disisi lain, sebagian besar ulama menyatakan bahwasanya akad nikah atau sigat nikah hanya dengan lafaz al-nikāh atau al-tazwīj sebagaimana yang tercantum dalam nas-nas Al-Qur'an dan Hadis.

Oleh karena itu, penulis merumuskan beberapa pokok masalah yang akan dibahas pada kajian ini tentang nikah dengan lafaz hibah, dan pandangan jumhur tentang nikah dengan lafaz hibah dan secara khusus pandangan Imam Abu Hanifah tentang nikah dengan lafaz hibah. Untuk mengkajinya secara komperehensif, maka metode penelitian yang digunakan adalah penelitian kepustakaan (library research) dengan pendekatan yuridis-normatif dengan cara meneliti berbagai bahan pustaka sebagai bahan dasar untuk menelusuri peraturan-peraturan dan literatur-literatur yang berkaitan dengan masalah yang dikaji ${ }^{4}$. Penulis juga menggunakan pendekatan analisis-komparatif, dan dalam hukum Islam pendekatan perbandingan dilakukan secara dialektis untuk menguji validasi argument dari masing-masing ketentuan hukum yang berbeda. Dokumen hukum Islam sarat dengan perbedaan pendapat antara para ulama fikih. Hal ini terutama disebabkan perbedaan metode penetapan hukum, atau yang dikenal dengan $u s h u l f i q h^{5}$.

Adapun penelitian terdahulu yang bersinggungan dengan tulisan ini di antaranya adalah hasil penelitian yang berjudul: "Perbedaan Lafaz Nikah Dalam Ijab Qabul Perspektif Majelis Ulama Indonesia Provinsi Lampung”, yang mana membahas tentang

\footnotetext{
${ }^{3}$ Muḥammad bin Ismāê̄l Abū 'Abdillāh al-Bukhārī, (al-Muhaqqiq: Muhammad Zuhaīr bin Nāṣir al-Nāṣir), Șaḥ̄ị al-Bukhārī jilid 3 (Cet I; t.t.: dār țauq al-Najāh, 2001), 26.

${ }^{4}$ Soejono Soekanto dan Sri Mamudji, Penelitian Hukum Normatif: Suatu Tinjauan Singkat (Jakarta: Rajawali Pers, 2001), 13-14.

${ }^{5}$ Hajar M, Model-Model Pendekatan Dalam Penelitian Hukum dan Fiqh (Cet I; Yogyakarta: Kalimedia, 2017), 87.
} 


\section{BUSTANUL FUQAHA: \\ JURNAL BIDANG HUKUM ISLAM \\ Vol. 2 No. 1 (2021): Hal. 1-23 \\ EISSN: 2723-6021 \\ Website: https://journal.stiba.ac.id}

perbedaan lafaz nikah dalam perspektif MUI Lampung. Hasil penelitian yang berjudul: "Studi Analisis Pendapat Ibnu Qudamah Tentang Keharusan ijab kabul Menggunakan Lafaz Inkah dan Tazwīj” yang membahas kepada penggunaan lafaz Inkah atau Tazwīj menurut pendapat Ibnu Qudamah. Berbeda dengan dua penelitian sebelumnya, tulisan ini membahas tentang penggunaan lafaz hibah menurut pendapat Jumhur dan Imam Abu Hanifah pada akad pernikahan.

\section{PEMBAHASAN}

\section{Pernikahan dan Hibah Menurut Perspektif Hukum Islam Pernikahan dalam Perspektif Hukum Islam}

Pernikahan atau perkawinan merupakan sunatullah yang umum dan berlaku pada semua makhluk Allah swt. baik pada manusia, hewan maupun tumbuh-tumbuhan, yang merupakan suatu cara yang dipilih oleh Allah swt. Sebagai jalan bagi makhluk-Nya untuk berkembang biak dan melestarikan hidupnya. Secara etimologi kata nikah memiliki beberapa arti yaitu berkumpul, bersatu, bersetubuh dan akad. Pada hakikatnya pernikahan bermakna persetubuhan. Kata nikah berasal dari bahasa arab نكاح yang merupakan masdar dari kata نكح kemudian diterjemahkan ke dalam bahasa Indonesia menjadi perkawinan. Di dalam Al-Qur'an kata nikah atau نكح yang berarti kawin terdapat dalam Qs. An Nisa/4:3,

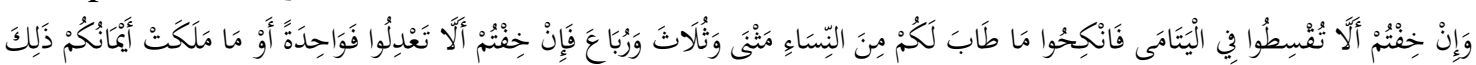

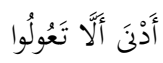

Terjemahnya:

"Dan jika kamu khawatir tidak akan mampu berlaku adil terhadap (hakhak) perempuan yatim (bilamana kamu menikahinya), maka nikahilah perempuan (lain) yang kamu senangi dua, tiga atau empat. Tetapi jika kamu khawatir tidak akan mampu berlaku adil, maka (nikahilah) seorang saja, atau hamba sahaya perempuan yang kamu miliki. Yang demikian itu lebih dekat agar kamu tidak berbuat zhalim"6.

Secara terminologi berarti ikatan yang menghalalkan hubungan laki-laki dan perempuan yang semula terlarang ${ }^{7}$. Kemudian di dalam buku Kisyaf Al- Qona' disebutkan bahwa nikah secara istilah atau syara' adalah:

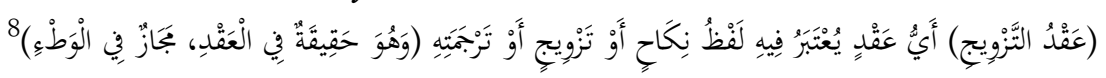

Terjemahnya:

"Akad nikah adalah akad pernikahan atau akad yang menganggap

\footnotetext{
${ }^{6}$ Kementrian Agama RI, Al-Qur'an dan Terjemahnya, 77.

${ }^{7}$ Muhammad bin Ahmad Al-Ramli, Ghoyah Al-Bayan Syarah Zubad Ibn Ruslan, (Beirut: Dar AlKutub Al-Islamiyah, 2012), 263.

${ }^{8}$ Mansur bin Yunus bin Sholahuddin bin Hasan bin Idris Al-Bahuty Al-Hanbaly, Qisyaf Al-Qona', An Matan Al-Iqna' (t.t. Dār Al-Kutub Al-Ilmiyah, t.th.), 5.
} 
didalamnya lafaz nikah dan al-tazwij yang hakikatnya adalah akad, kiasan dari al-waț' (jima')"'.

Adapun hukum pernikahan dalam Islam ulama berbeda pendapat atasnya, di dalam buku Bidāyatul Mujtahid disebutkan:

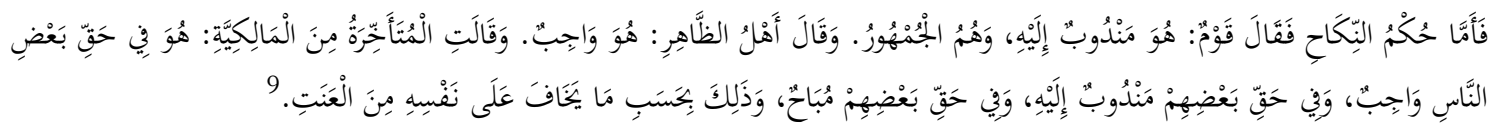

Terjemahnya:

"Hukum nikah sebagian kaum mengatakan sunah yaitu kaum jumhur ulama, dan ahlu zohir berkata hukum nikah adalah wajib dan berkata orang-orang dari mazhab Malikiyah bahwasanya hukumnya tergantung dari setiap pribadi masing-masing berdasarkan bagaiman ketakutan dalam dirinya dalam menjaga."

\section{Rukun dan Syarat Pernikahan}

Dalam mewujudkan pernikahan yang sah dan seusai dengan aturan yang berlaku pastinya harus memenuhi beberapa rukun dan syarat, berikut ini adalah rukun dan syarat penikahan.

Rukun nikah yaitu:

1. Sepasang suami istri, haruslah jelas adanya calon suami dan calon istri dan tidak boleh berasal dari orang-orang yang telah diharamkan untuk dinikahi.

2. Lafaz ijab, yaitu lafaz yang dilontarkan oleh seorang wali atau yang mewakilinya kepada sang calon suami.

3. Lafaz kabul, yaitu lafaz yang dilontarkan calon suami dengan perkataan saya terima nikahnya $^{10}$.

Syarat nikah:

1. Kejelasan dari pasangan suami istri, tidak sah suatu pernikahan jika salah satu dari calon tidak jelas seperti perkataan saya nikahkan engkau dengan anak saya, dan kita tidak tahu bahwasanya anak yang mana yang dimaksudkan di sini.

2. Rida dari sepasang calon suami istri, tidak sah sebuah akad jika terdapat unsur kepaksaan.

3. Wali, tidak sah akad seorang istri jika tidak ada wali.

4. Dua saksi yang adil dan jujur.

5. Terbebas dari salah satu penyebab dari dilarangnya penikahan, seperti; penyebab nasab, beda agama dan lain-lain dari penyebab dilarangnya sebuah pernikahan ${ }^{11}$.

9 Abi Al-Walīd Muhammad Bin Ahmad Bin Muhammad Bin Ahmad Bin Rusyd Al-Qurțobi AlAndalusy, Bidāyatul Mujtahid Wa Kifāyatul Muqtașid (t.t Dār Al-Hadis, 1425 H/2004 M), 30.

${ }^{10}$ Majmūatun minal muallifīn, Al-Fiqhu Al-Muyassar Fii Daui Al-Kitab Wa As-Sunnah (Cet. I; t.t. Mujma’ al-mulk litobaatil al-mushaf as-syarif, 1424 H/ 2003 M), 296.

${ }^{11}$ Majmūatun minal muallifīn, Al-Fiqhu Al-Muyassar Fii Daui Al-Kitab Wa As-Sunnah, 295. 


\section{BUSTANUL FUQAHA: \\ JURNAL BIDANG HUKUM ISLAM \\ Vol. 2 No. 1 (2021): Hal. 1-23 \\ EISSN: 2723-6021 \\ Website: https://journal.stiba.ac.id}

\section{Hibah dalam Perpektif Hukum Islam}

Hibah adalah istilah syariat yang sudah menjadi perbendaharaan bahasa Indonesia, sehingga istilah ini bukan lagi suatu hal yang asing. Hibah merupakan bagian dari tolong menolong dalam kebaikan yang diperintahkan agama Islam. Dalam hukum Islam, seseorang diperbolehkan untuk memberikan atau menghadiahkan sebagian harta kekayaan ketika masih hidup kepada orang lain. Pemberian semasa hidup itu sering disebut sebagai hibah. Allah swt. mensyariatkan hibah karena mendekatkan hati dan menguatkan tali cinta antara manusia, sebagaimana hadis yang disabdakan Rasulullah saw.:

$$
\text { عن أبي هريرة رضي الله عنه أن النبي صلى الله عليه وسلم قال: قحادوا تحابوا (رواه البخاري) }
$$

Artinya:

"Dari Abu Hurairah ra. bahwasanya nabi saw. bersabda: saling memberilah kalian, niscaya kalian akan saling mencintai (Hadis riwayat Al-Bukhari no. 594)"12.

Kata hibah berasal dari bahasa Arab dari kata (هبة) yang berarti pemberian yang dilakukan seseorang saat dia masih hidup kepada orang lain tanpa imbalan (pemberian cuma-cuma), baik berupa harta atau bukan harta. Di antaranya kata ini digunakan dalam firman Allah Azza wa Jalla dalam Qs. Maryam/19:5-6.

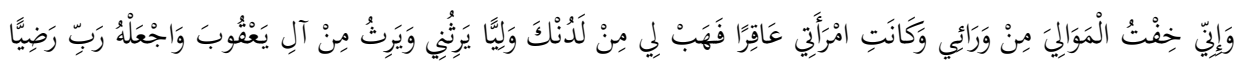

Artinya:

"Dan sesungguhnya aku khawatir terhadap mawaliku sepeninggalku, sedang isteriku adalah seorang yang mandul, maka anugerahilah aku dari sisi Engkau seorang putra yang akan mewarisi aku dan mewarisi sebahagian keluarga Yáqub dan jadikanlah ia, ya Rabbku, seorang yang diridai" ${ }^{13}$.

Sedangkan pengertian hibah menurut para ulama ahli fikih, disampaikan syaikh Abdurrahmân As-Sa'di rahimahullah dengan ungkapan: "Pemberian harta cuma-cuma dalam keadaan hidup dan sehat," dan dengan demikian pengertian hibah adalah pemberian yang dilakukan oleh seseorang kepada pihak lain yang dilakukan ketika masih hidup dan dalam keadaan sehat, sehingga serah terima harta yang diberikan itu dilakukan pada waktu penghibah masih hidup ${ }^{14}$. Imam Wahbah Al-Zuhaily mengatakan dalam bukunya Al-Fiqhu Al-Islāmy Wa Adillatuhu bahwasanya: Hibah adalah akad interaksi

\footnotetext{
${ }^{12}$ Muḥammad bin Ismā‘̄̄l bin Ibrāhīm bin al-Mugīrah al-Bukhārī, (al-Muhaqqiq: Muḥammad Nāṣir al-Dīn al-Albānī), Șahīị al-Adab al-Mufrad lī al-Imām al-Bukhārī, Cet. IV (t.t.: Dār al-Ṣadīq lī alNasyr wa al-Tauzī', 1997), 221.

${ }^{13}$ Kementrian Agama RI, Al-Qur'an dan Terjemahnya, 305.

14 Khalid Syamhudi, "Hibah dalam Perspektif Fikih", last modified Februari 08, 2021 https://almanhaj.or.id/6422-hibah-dalam- perspektif-fikih.html.
} 


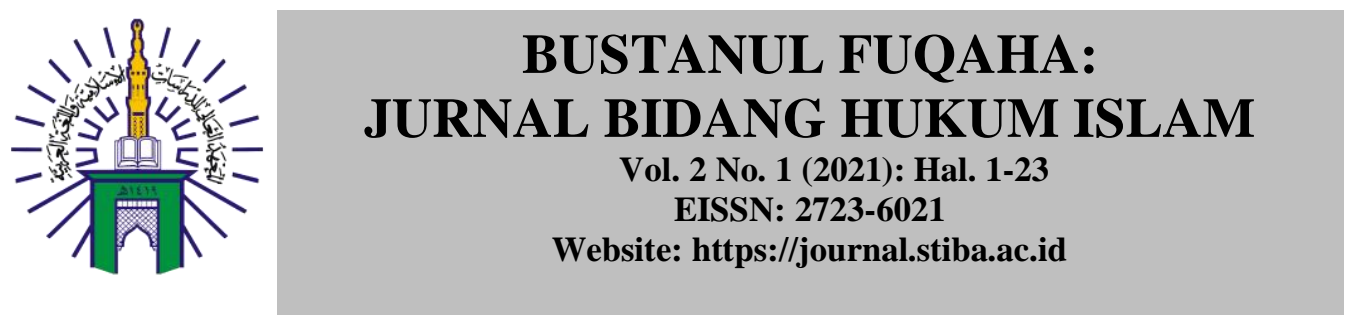

yang berkenan tentang seseorang yang memberikan hartanya tanpa meminta balasan, dan para ulama mengartikan hibah dengan akad yang bermanfaat bagi para pemberi sepanjang hidupnya dengan sukarela ${ }^{15}$.

Adapun hukum hibah dalam Islam boleh-boleh saja, Allah swt. berfirman dalam Q.S An-Nisa/4: 4,

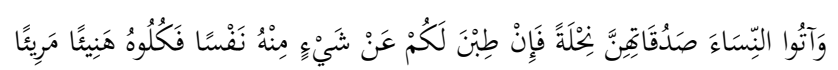

Terjemahnya:

"Dan berikanlah maskawin (mahar) kepada perempuan (yang kamu nikahi) sebagai pemberian yang penuh kerelaan. Kemudian, jika mereka menyerahkan kepada kamu sebagian dari (maskawin) itu dengan senang hati, maka terimalah dan nikmatilah pemberian itu dengan senang hati" ${ }^{\prime \prime}$.

Ayat di atas menjelaskan bahwa bolehya memberi dan menerima sesuatu dengan senang hati, hal ini menandakan bahwa bolehnya hibah dalam agama Islam. Akan tetapi jika hibah dimasukkan kedalam kata sebuah akad nikah atau dijadikan sebagai lafaz nikah apakah hal tersebut dibolehkan, maka hal inilah yang akan menjadi dialektika dalam kanjian ini, dan dikarenakan ulama berbeda pendapat akan hal tersebut, maka hal inilah yang dijadikan titik tolah bagi penulis dalam membandingkan pendapat antara jumhur ulama dan Imam Abu Hanifah.

\section{Rukun dan Syarat Hibah}

Untuk bisa melakukan hibah dengan benar dan sesuai anjuran syariat Islam maka harus memenuhi rukun dan syaratnya, dan mayoritas ulama memandang bahwa hibah memiliki empat rukun yaitu: orang yang memberi (Al-Wāhib), orang yang diberi (AlMauhūb lahu), benda yang diberi (Al-Mauhūb) dan tanda serah terima (Shigat). Adapun syarat sebuah hibah adalah:

1. Bahwasanya dia mampu untuk melakukannya, dan dia termasuk orang yang bebas atau bukan budak dan berakal.

2. Bahwasanya al-Wăhib atau sang pemberi tidak dalam keadaan terpaksa atau dipaksa untuk melakukannya.

3. Bahwasanya al-Mauhūb atau barang yang akan diberi adalah barang yang halal, dan tidak sah jika memberi dangan barang yang diharamkan seperti; miras, daging babi dan lain-lain.

4. Bahwasanya harus ada sebuah akad atau ijab dan kabul antara sang pemberi dan penerima hibah.

5. Bahwasanya hibah haruslah selamanya bukan pemberian yang memiliki batas waktu, seperti, saya hibahkan benda ini kepadamu selama satu bulan atau satu tahun maka hal ini tidaklah benar dan bukan termasuk dalam bentuk hibah.

\footnotetext{
${ }^{15}$ Wahbah Bin Musțofa Al-Zuhaily, Al-Fiqhu Al-Islāmy Wa Adillatuhu (Cet. 4; t.d.), 3260.

${ }^{16}$ Kementrian Agama RI, Al-Qur'an dan Terjemahnya, 77.
} 
6. Bahwasanya hibah tidak mengharuskan sang penerima untuk menggantinya, jika penerima hibah merusak benda atau menghilangkan benda hibah tersebut ${ }^{17}$.

\section{Riwayat Hidup Imam Abu Hanifah dan Jumhur Biografi Imam Abu Hanifah}

Abu Hanifah dilahirkan pada tahun 80 Hijriah (696 M) dan meninggal di Kufah pada tahun 150 Hijriah $(767 \mathrm{M})$. Abu Hanifah hidup selama 52 tahun dalam masa Amawiyah dan 18 tahun dalam masa Abbasi, sehingga segala daya pikir, daya cepat tanggapnya dimiliki di masa Amawi, walaupun akalnya terus tembus dan ingin mengetahui apa yang belum diketahui, istimewa akal ulama yang terus mencari tambahan. Adapun nama beliau dari kecil ialah Nu'man bin Tsabit bin Zauta bin Mah. Ayah beliau keturunan dari bangsa Persi (Kabul-Afganistan), tetapi sebelum beliau dilahirkan, ayahnya sudah pindah ke Kufah. Oleh karena itu, beliau bukan keturunan bangsa Arab asli, tetapi dari bangsa Ajam (bangsa selain bangsa Arab) dan beliau dilahirkan di tengah-tengah keluarga berbangsa Persia ${ }^{18}$. Setelah Abu Hanifah menjadi seorang ulama besar dan terkenal di segenap kota-kota besar, serta terkenal di sekitar Jazirah Arabiyah pada umumnya, maka beliau dikenal pula dengan gelar Imam Abu Hanifah. Setelah ijtihad dan buah penyelidikan beliau tentang hukum-hukum keagamaan diakui serta diikuti oleh banyak orang dengan sebutan "Mazhab Imam Hanafi" "19.

Ciri-ciri Abu Hanifah yaitu dia berperawakan sedang dan termasuk orang yang mempunyai postur tubuh ideal, paling bagus logat bicaranya, paling bagus suaranya saat bersenandung dan paling bisa memberikan keterangan kepada orang-orang yang diinginkannya (menurut pendapat Abu Yusuf), serta Abu Hanifah berkulit sawo matang dan tinggi badannya, berwajah tampan, berwibawa dan tidak banyak bicara kecuali menjawab pertanyaan yang dilontarkan, dan beliau tidak mau mencampuri persoalan yang bukan urusannya (menurut Hamdan putranya) ${ }^{20}$.

Abu Hanifah suka berpakaian yang baik-baik serta bersih, senang memakai wewangian dan suka duduk di tempat duduk yang baik. Lantaran dari kesukaannya dengan wewangian, hingga beliau dikenal oleh orang ramai tentang kewangiannya, sebelum mereka melihat kepadanya. Abu Hanifah juga amat suka bergaul dengan saudara-saudaranya dan para kawan-kawannya yang baik-baik, tetapi tidak suka bergaul

\footnotetext{
${ }^{17}$ Majmūatun minal muallifīn, Al-Fiqhu Al-Muyassar Fii Daui Al-Kitab Wa As-Sunnah, (Cet. I: t.t. Majma’ Malik Fadh Li Thibaah Mushaf Syarif 1424 H/ 2003 M), 269.

${ }_{18}$ Moenawir Chalil, Biografi Empat Serangkai Imam Mazhab Hanafi, Maliki, Syafi'i, Hambali, (Jakarta: Bulan Bintang, 1955).

${ }_{19}$ Moenawir Chalil, Biografi Empat Serangkai Imam Mazhab Hanafi, Maliki, Syafi'i, Hambali, (Jakarta: Bulan Bintang, 1955), 20.

${ }^{20}$ Syaikh Ahmad Farid, Min A 'lam As-Salaf, Trans. Masturi Ilham, Asmu'i Taman, (Jakarta: Pustaka Kautsar, 2007).
} 


\section{BUSTANUL FUQAHA: \\ JURNAL BIDANG HUKUM ISLAM \\ Vol. 2 No. 1 (2021): Hal. 1-23 \\ EISSN: 2723-6021 \\ Website: https://journal.stiba.ac.id}

dengan sembarangan orang. Berani menyatakan sesuatu hal yang terkandung di dalam hati sanubarinya, dan berani pula menyatakan kebenaran kepada siapa pun juga, tidak takut dicela ataupun dibenci orang, dan tidak pula gentar menghadapi bahaya bagaimanapun keadaannya ${ }^{21}$.

\section{Pendidikan Imam Abu Hanifah}

Pada mulanya Abu Hanifah adalah seorang pedagang, karena ayahnya adalah seorang pedagang besar. Pada waktu itu Abu Hanifah belum memusatkan perhatian kepada ilmu, turut berdagang di pasar, menjual kain sutra. Di samping berniaga, ia tekun menghapal Al-Qur'an dan amat gemar membacanya. Kecerdasan otaknya menarik perhatian orang-orang yang mengenalnya, karena Asy-Sya'bi menganjurkan supaya Abu Hanifah mencurahkan perhatiannya kepada ilmu. Dengan anjuran Asy-Sya'bi mulailah Abu Hanifah terjun ke lapangan ilmu. Namun demikian Abu Hanifah tidak melepas usahanya sama sekali ${ }^{22}$.

Imam Abu Hanifah pada mulanya gemar belajar ilmu qira'at, hadis, nahwu, sastra, syair, teologi dan ilmu-ilmu lainnya yang berkembang pada masa itu. Di antara ilmu-ilmu yang dicintainya adalah ilmu teologi, sehingga beliau salah seorang tokoh yang terpandang dalam ilmu tersebut. Oleh karena ketajaman pemikirannya, beliau sanggup menangkis serangan golongan khawarij yang doktrin ajarannya sangat ekstrim. Selanjutnya, Abu Hanifah menekuni ilmu fikih di Kufah yang pada waktu itu merupakan pusat perhatian para ulama fikih yang cenderung rasional, di Irak terdapat Madrasah Kufah yang dirintis oleh Abdullah ibn Mas'ud (wafat 63 H/682 M). Kepemimpinan Madrasah Kufah kemudian beralih kepada Ibrahim Al-Nakha'i, lalu Muhammad ibn Abi Sulaiman Al-Asy'ari (wafat 120 H). Hammad ibn Sulaiman adalah salah seorang Imam besar (terkemuka) ketika itu. Ia murid dari 'Alqamah ibn Qais dan Al-Qadhi Syuri'ah, keduanya adalah tokoh dan fakar fikih yang terkenal di Kufah dari golongan tabiin. Dari Hamdan ibn Sulaiman itulah Abu Hanifah belajar fikih dan hadis. Selain itu, Abu Hanifah beberapa kali pergi ke Hijaz untuk mendalami fikih dan hadis sebagai nilai tambahan dari apa yang diperoleh di Kufah. Sepeninggal Hammad, majelis Madrasah Kufah sepakat mengangkat Abu Hanifah menjadi kepala Madrasah. Selama itu ia mengabdi dan banyak mengeluarkan fatwa dalam masalah fikih. Fatwa-fatwanya itu merupakan dasar utama dari pemikiran Mazhab Hanafi yang dikenal sekarang ini2 ${ }^{23}$.

Setelah menyelesaikan pendidikannya di Kufah dan Basrah, Abu Hanifah pergi ke Makkah dan Madinah sebagai pusat dari ajaran agama Islam. Lalu bergabung sebagai murid dari ulama terkenal Atha' bin Abi Rabah. Guru Abu Hanifah kebanyakan dari

${ }^{21}$ Moenawir Chalil, Biografi Empat Serangkai Imam Mazhab Hanafi, Maliki, Syafi'i, Hambali, (Jakarta: Bulan Bintang, 1955), 21.

${ }^{22}$ Hendri Andi Bastoni, 101 Kisah Tabi'in, (Cet. 1; Jakarta: Pustaka al-Kausar, 2006), 46.

${ }^{23}$ Huzaimah Tahido Yanggo, Pengantar Perbandingan Mazhab, (Cet. 1; Jakarta: Logos Wacana Ilmu, 1997), 95. 


\section{BUSTANUL FUQAHA: \\ JURNAL BIDANG HUKUM ISLAM \\ Vol. 2 No. 1 (2021): Hal. 1-23 \\ EISSN: 2723-6021 \\ Website: https://journal.stiba.ac.id}

kalangan tabiin. Di antara mereka itu ialah Imam Atha bin Abi Raba'ah (wafat pada tahun 114 H), Imam Nafi' Maula Ibnu Umar (wafat pada tahun $117 \mathrm{H}$ ), dan lain-lain lagi. Adapun orang alim ahli fikih yang menjadi guru beliau yang paling masyhur ialah Imam Hamdan bin Abu Sulaiman (wafat pada tahun $120 \mathrm{H}$ ), Imam Hanafi berguru kepada beliau sekitar 18 tahun. Di antara orang yang pernah menjadi guru Imam Abu Hanifah ialah Imam Muhammad al-Baqir, Imam Ady bin Tsabit, Imam Abdur Rahman bin Harmaz, Imam Amr bin Dinar, Imam Manshur bin Mu'tamir, Imam Syu'bah bin Hajjaj, Imam Ashim bin Abin Najwad, Imam Salamah bin Kuhail, Imam Qatadah, Imam Rabi'ah bin Abi Abdur Rahman, dan lain-lainnya dari ulama tabiin dan tabi'it tabi' in $^{24}$.

\section{Metode Istinbat Imam Abu Hanifah}

Pola pemikiran Imam Abu Hanifah dalam menetapkan hukum sudah tentu sangat dipengaruhi latar belakang kehidupan serta pendidikannya, juga tidak terlepas dari sumber hukum yang ada. Abu Hanifah dikenal sebagai Ulama al-Ra'yi dalam menetapkan hukum Islam, baik yang diistinbatkan dari Al-Qur'an ataupun hadis, serta beliau banyak menggunakan nalar. Dari keterangan tersebut, tampak bahwa Imam Abu Hanifah dalam menetapkan hukum syariat yang tidak ditetapkan dalalahnya secara qath'iy menggunakan ra'yu atau pemikiran dalam menetapkan hukum, Abu Hanifah dipengaruhi oleh perkembangan hukum di Kufah, yang terletak jauh dari Madinah sebagai kota tempat tinggal Rasulullah $\mathrm{saw}^{25}$. Adapun Imam Abu Hanifah dalam menetapkan suatu hukum yang belum ada hukumnya di dalam Al-Qur'an ataupun hadis, maka beliau menggunakan beberapa metode dalam menetapkannya, yaitu:

1. Al-Qur'an;

2. Sunah (hadis-hadis nabi);

3. Perkataan sahabat (Al-Atsar);

4. Ijmak;

5. Kias;

6. Istihsan;

7. Al-'Urf (kebiasaan) $)^{26}$.

\section{Jumhur ulama}

Pengertian jumhur dalam Kamus Besar Bahasa Indonesia (KBBI) bermakna golongan terbanyak atau mayoritas ${ }^{27}$, dan yang dimaksud dalam kajian ini adalah

\footnotetext{
${ }^{24}$ Moenawir Chalil, Biografi Empat Serangkai Imam Mazhab Hanafi, Maliki, Syafi'I,. Hambali, (Jakarta: Bulan Bintang, 1955), 22-23.

${ }^{25}$ Huzaimah Tahido Yanggo, Pengantar Perbandingan Mazhab, (Cet. 1; Jakarta: Logos Wacana Ilmu, 1997), 97.

${ }^{26}$ Abdullah Bin Abdul Muhsin Al-Toriqi, khulașațu tārīkh at-tasyrī’ (Cet. 2; t.t. t.p. 1432 H/ 2011 M), 83-84.

${ }^{27}$ KBBI Daring, Jumhur, https://kbbi.kemdikbud.go.id/entri/jumhur.
} 


\section{BUSTANUL FUQAHA: \\ JURNAL BIDANG HUKUM ISLAM \\ Vol. 2 No. 1 (2021): Hal. 1-23 \\ EISSN: 2723-6021 \\ Website: https://journal.stiba.ac.id}

golongan terbanyak dari empat ulama-ulama mazhab yang terkenal. Jadi, jika seandainya yang disebutkan adalah Imam Abu Hanifah dan jumhur maka yang dimaksud dengan jumhur di sini adalah tiga ulama mazhab yang lainya yaitu; Imam Malik, Imam As-Syāfi' dan Imam Ahmad.

\section{Imam Malik}

Imam Malik adalah Imam yang kedua dari imam-imam empat serangkai dalam Islam. Ia dilahirkan tiga belas tahun sesudah kelahiran Abu hanifah. Imam Malik ialah seorang imam dari Kota Madinah dan imam bagi penduduk Hijaz. Ia salah seorang ahli fikih yang terakhir bagi kota Madinah dan juga terakhir bagi fuqaha Madinah, beliau berumur hampir sembilan puluh tahun ${ }^{28}$. Imam Malik dilahirkan di Kota Madinah daerah negeri Hijaz, lebih tepatnya di suatu tempat yang bernama Zulmarwah, di utara Madinah Al-Munawwarah, kemudian Imam Malik tinggal di Al-Akik lalu pindah ke Madinah. Menurut riwayat yang masyhur Imam Malik lahir tahun 93 H (712 M) ${ }^{29}$. Silsilah keturunan Imam Malik sebagai berikut: Malik bin Anas bin Malik bin Abi Amir bin Amru bin Ghaiman bin Huthail bin Amru bin Al-Haris, dan Imam Malik termasuk pendukung suku (Bani) Tamim bin Murrah. Datuknya yang kedua "Abu Amir bin Amru" salah seorang sahabat Rasulullah saw. yang ikut berperang bersama Rasul, kecuali dalam perang Badar. Sedangkan datuk Imam Malik yang pertama yaitu Malik bin Amar dari golongnan tabiin gelarannya ialah Abu Anas. Sejarah Anas, bapaknya Imam Malik tidak disebutkan dalam buku-buku sejarah. Ibu Imam Malik bernama Al-Ghalit binti Syarik bin Abdul Rahman bin Syarik Al-Azdiyyah dan ada pula yang mengatakan namanya Thalhah, tetapi dia lebih dikenal dengan nama yang pertama. Dengan riwayat ini teranglah bahwa Imam Malik adalah seorang dari keturunan bangsa Arab dari dusun Dzu Ashbah, sebuah dusun di Kota Himyar dari jajahan negeri Yaman ${ }^{30}$.

Imam Malik belajar di Kota Madinah dalam suasana lingkungan yang meliputi di antaranya para sahabat, para tabiin dan para ahli hukum agama. Beliau terdidik di tengahtengah mereka itu, dan dikenal sebagai seorang anak yang cerdas pikirannya, cepat menerima pelajaran, kuat dalam berpikir dan menerima pengajaran, setia dan teliti. Beliau sudah hafal Al-Qur'an dalam usia yang sangat dini. Sekitar umur 10 tahun, Imam Malik telah menghafalkan Al-Qur-an dengan sejumlah hadis. Wawasannya telah terpenuhi dengan cahaya kalimat-kalimat Allah swt. Imam Malik sangat rajin dan tekun dalam mencari ilmu apapun, padahal beliau bukanlah termasuk orang kaya. Akan tetapi semua yang dimilikinya untuk mencari ilmu sampai beliau pernah menjual atap rumahnya hanya untuk bekal mencari ilmu. Imam malik mengawali pelajarannya dengan menekuni ilmu

${ }^{28}$ Ahmad Asy-Syurbasi, Sejarah dan Biografi Empat Imam Mazhab (Jakarta: Amzah,2001), 71.

${ }^{29}$ Moenawir Chalil, Biografi Empat Serangkai Imam Mazhab Hanafi, Maliki, Syafi'i, Hambali, (Jakarta: Bulan Bintang, 1955), 84.

${ }^{30}$ Ahmad Asy-Syurbasi, Sejarah dan Biografi Empat Imam Mazhab, (Jakarta: Amzah, 2001), 73. 


\section{BUSTANUL FUQAHA: \\ JURNAL BIDANG HUKUM ISLAM \\ Vol. 2 No. 1 (2021): Hal. 1-23 \\ EISSN: 2723-6021 \\ Website: https://journal.stiba.ac.id}

riwayat hadis, mempelajari fatwa para sahabat dan dengan inilah membangun mazhabnya. Imam malik tidak hanya berhenti sebatas itu, beliau mengkaji setiap ilmu yang ada hubungannya dengan ilmu syariat. Beliau memiliki firasat yang tajam dalam menilai orang dan mengukur kekuatan fikih mereka ${ }^{31}$.

Diwaktu Imam Malik menuntut ilmu, beliau mepunyai guru banyak. Kitab "Tahzibul Asma Wallughat" menerangkan bahwa Imam Malik pernah belajar kepada Sembilan ratus orang syekh. Tiga ratus darinya dari golongan tabiin dan enam ratus lagi dari tabi'ut-tabi'in. Mereka semua adalah orang yang terpilih dan cukup dengan syarat yang dapat dipercaya dalam bidang agama dan hukum fikih. Di antara guru-guru Imam Malik adalah: Abdul Rahman bin Harmuz Al-'Araj, Rabi'ah bin Abdul Rahman Furuk, Nafi'i 'Auli Abdullah, Ja'far bin Muhammad Al-Baqir, Muhammad bin muslim az-zuhri, Abdul Rahman bin Zakuan, Yahya bin Said Al-Ansari, Abu Hazim Salmah bin Dinar, dan masih banyak lagi dari golongan tabiin sebagaimana yang diterangkan oleh AnNawawi ${ }^{32}$.

\section{Imam As-Syāfi'i}

Imam Syāfi'i dari segi urutan masa merupakan Imam ketiga dari empat Imam yang masyhur. Beliau adalah ulama mujtahid (ahli ijtihad) dibidang fikih dan salah seorang dari empat Imam Mazhab yang terkenal dalam Islam. Ia hidup di masa pemerintahan khalifah Harun al-Rasyid, al-Amin dan al-Ma'mun dari dinasti Abbasiyah. Nama lengkap Imam Syāfi'i adalah Abu Abdullah Muhammad ibn Idris As-Syāfi'i. Ia sering juga dipanggil dengan nama Abu Abdullah, karena salah seorang putranya bernama Abdullah. Setelah menjadi ulama besar dan mempunyai banyak pengikut, ia lebih dikenal dengan nama Imam Syāfi'i dan mazhabnya disebut Mazhab Syāfi'i. Kata Syāfi'i dinisbatkan kepada nama kakeknya yang ketiga, yaitu Syāfi'i bin al-Saib. Ayahnya bernama Idris bin Abbas bin Usman bin Syafi'I bin al-Saib bin Abdul Manaf, sedangkan ibunya bernama Fatimah binti Abdullah bin al-Hasan bin Husain bin Ali bin Abi Thalib. Dari garis keturunan ayahnya, Imam Syāfi'i bersatu dengan keturunan Nabi Muhammad saw ${ }^{33}$.

Imam Syāfi'i menuntut ilmu di Makkah dan mahir disana. Ketika Muslim bin Khalid az-Zanji memberikan peluang untuk berfatwa, Imam Syāfi'i merasa belum puas atas jerih payahnya selama ini. Ia terus menuntut ilmu hingga akhirnya pindah ke Madinah dan bertemu dengan Imam Malik. Sebelumnya ia telah mempersiapkan diri membaca kitab Al-Muwaththa' (karya Imam Malik) yang sebagian besar telah

${ }^{31}$ Rasyad Hasan Khalil, Tarikh Tasyri', Sejarah Legislasi Hukum Islam (Jakarta: Amzah, 2009), h. 179.

${ }^{32}$ Rasyad Hasan Khalil, Tarikh Tasyri', Sejarah Legislasi Hukum Islam (Jakarta: Amzah, 2009), 181.

${ }^{33}$ Moenawir Chalil, Biografi Empat Serangkai Imam Mazhab Hanafi, Maliki, Syafi'i, Hambali, (Jakarta: Bulan Bintang, 1955), 147. 
dihafalnya. Ketika Imam Malik bertemu dengan Imam Syāfi'i, Imam Malik berkata, "Sesungguhnya Allah swt. telah menaruh cahaya dalam hatimu, maka jangan padamkan dengan perbuatan maksiat." Mulailah Imam Syāfi'i belajar dari Imam Malik dan senantiasa bersamanya hingga Imam Malik wafat pada tahun 179 H. Selama itu juga ia mengunjungi ibunya di Makkah. Kematian Imam Malik berpengaruh besar terhadap kehidupan Imam Syafi'i. Semula ia tidak pernah memikirkan keperluan-keperluan penghidupannya, tetapi setelah kematian gurunya, hal itu menjadi beban pikiran yang tidak dapat di atasinya ${ }^{34}$.

Setelah belajar kepada Imam Malik, pada tahun 195 H. beliau pergi ke Baghdad untuk menuntut ilmu dan mengambil pendapat-pendapat dari murid-murid Imam Abu Hanifah, dengan cara bermunazara dan berdebat dengan mereka, selama dua tahun beliau berada di Baghdad kemudian beliau ke Makkah, dilanjutkan ke Yaman, beliau berguru pada Matrak bin Mazin dan di Irak beliau berguru kepada Muhammad bin Hasan. Di antara guru-guru beliau ada yang beraliran tradisional atau aliran hadis. Seperti Imam Malik dan ada pula yang mengikuti paham Muktazilah dan Syiah. Pengalaman yang diperoleh Imam Syafi'i dari berbagai aliran fikih tersebut membawanya ke dalam cakrawala berpikir yang luas, beliau mengetahui letak keturunan dan kelemahan, luas dan sempitnya pandangan masing-masing mazhab tersebut, dengan bekal itulah beliau melangkah untuk mengajukan berbagai kritik dan kemudian mengambil jalan keluarnya sendiri. Mula-mula beliau berbeda pendapat dengan gurunya Imam Malik. Perbedaan ini berkembang sedemikian rupa sehingga ia menulis buku Khilaf Malik yang sebagian besar berisi kritik terhadap pendapat fikih mazhab gurunya itu. Beliau juga terjun dalam perdebatan-perdebatan sengit dengan madzhab Hanafi dan banyak mengeluarkan koreksi terhadapnya. Dari kritik-kritik Imam Syafi'i terhadap kedua mazhab tersebut akhirnya ia muncul dengan mazhab baru yang merupakan sintesis antara fikih ahli hadis dan fikih ahli rakyu yang benar-benar orisinil. Namun, demikian yang paling menentukan orisinalitas Mazhab Syāfí'i ini adalah kehidupan empat tahunnya di Mesir ${ }^{35}$.

Imam Syāfi'I memiliki banyak guru diberbagai tempat seperti di Makkah, Madinah, Irak dan Yaman. Ulama-ulama Mekkah yang menjadi gurunya adalah: Muslim bin Khalid az-Zanji, Sufyan bin Uyainah, Said bin al-Kudah, Daud bin Abdurrahman, AlAttar Abdul Hamid ibn Abdul Aziz ibn Abi Daud ${ }^{36}$. Ulama-ulama Madinah yang menjadi gurunya adalah: Malik bin Anas, Ibrahim bin Sa'ad al-Ansari, Abdul Azis bin Muhammad al-Darawardi, Ibrahim bin Yahya al-Asami, Muhammad Said bin Abi Fudaik, Abdullah bin Nafi al-Shani ${ }^{51}$. Ulama-ulama Irak yang menjadi gurunya adalah:

\footnotetext{
${ }^{34}$ Ahmad Asy-Syurbasi, Sejarah dan Biografi Empat Imam Mazhab, (Jakarta: Amzah, 2001), 131.

${ }^{35}$ Faruk Abu Zaid, Hukum Islam antara Tradisional dan Modernis, (Jakarta, Bulan Bintang, 1986), 29.

${ }^{36}$ Moenawir Chalil, Biografi Empat Serangkai Imam Mazhab Hanafi, Maliki, Syafi'i, Hambali, (Jakarta: Bulan Bintang, 1955), 149.
} 


\section{BUSTANUL FUQAHA: \\ JURNAL BIDANG HUKUM ISLAM \\ Vol. 2 No. 1 (2021): Hal. 1-23 \\ EISSN: 2723-6021 \\ Website: https://journal.stiba.ac.id}

Waki ibn Jarrah, Abu Usamah, Hammad ibn Usamah, Ismail ibn Ulaiyah, Abdul Wahab ibn Ulaiyah, Muhammad ibn Hasan. ${ }^{37}$ Ulama-ulama Yaman yang menjadi gurunya adalah: Muththarif ibn Mizan, Hisyam ibn Yusuf, Hakim Shan'a (Ibu Kota Republik Yaman), Umar ibn Abi Maslamah al-Auza'i, Yahya Hasan ${ }^{38}$.

\section{Imam Ahmad}

Ahmad bin Muhammad bin Hanbal adalah Imam yang keempat dari fukaha Islam. Beliau adalah seorang yang mempunyai sifat-sifat yang luhur dan tinggi yaitu sebagaimana dikatakan oleh orang-orang yang hidup semasa dengannya, juga orang yang mengenalnya. Beliau Imam bagi umat Islam seluruh dunia, juga Mufti bagi negeri Irak dan seorang yang alim tentang hadis-hadis Rasulullah saw. Juga seorang yang zuhud dewasa itu, penerang untuk dunia dan sebagai contoh dan teladan bagi orang-orang ahli sunah, seorang yang sabar dikala menghadapi percobaan, seorang yang saleh dan zuhud ${ }^{39}$. Nama lengkap dari seorang Imam Ahmad adalah Ahmad bin Muhammad bin Hanbal bin Hilal bin Asad bin Idris bin Abdillah bin ibn Hayyan bin Abdillah bin Anas bin 'Auf bin Qasit bin Mukhazin bin Syaiban bin Zahl bin Sa'labah bin 'Ukabah bin Sa'b bin 'Ali bin Bakr bin Wa'il bin Qasit bin Hanb bin Aqsa bin Du'ma bin Jadilah bin Asad bin Rabi'ah bin Nizar bin Ma'ad bin 'Adnan bin 'Udban bin al-Hamaisa' bin Haml bin an-Nabt bin Qaizar bin Isma'il bin Ibrahim asy-Syaibani al-Marwazi ${ }^{40}$.

Imam Ahmad lahir di Baghdad pada masa pemerintahan 'Abbasiyyah dipegang oleh al-Ma'mun, yaitu pada bulan Rabi' al-Awwal 164H/ November $780 \mathrm{M}$ dan meninggal dunia pada tanggal 12 Rabi' al-Awwal 241 H/31 Juli 855 M. Ayah Imam Ahmad bernama Muhammad bin Hanbal as-Syaibani. Jadi sebutan Hanbal bukanlah nama ayahnya tapi nama kakeknya. Ibunya bernama Safiyyah binti Maimunah binti 'Abd al-Malik bin Sawadah bin Hindun as-Syaibani. Silsilah Imam Ahmad bertemu dan bersambung dengan silsilah Nabi Muhammad saw. sampai di Nizar, karena yang menurunkan Nabi Muhammad saw. adalah Mudar bin Nizar datuk Nabi kita yang kedelapan belas. Hal ini menunjukkan bahwa Imam Ahmad mempunyai nasab yang tinggi dan terhormat ${ }^{41}$. Imam Ahmad lahir ditengah-tengah keluarga yang mulia, yang memiliki kebesaran jiwa, kekuatan kemauan dan tahan derita. Ayah Imam Ahmad meninggal dunia ketika beliau masih kecil, sehingga beliau hanya diasuh dan dididik oleh ibunya. Karena itu beliau mengalami keadaan hidup yang sangat sederhana. Karena itu

37 Farouq Abu Zaid, Hukum Islam antara Tradisional dan Modernis, (Jakarta: Perhimpunan Pengembangan Pesantren dan Masyarakat , 1986), 33.

38 Ahmad Asy-Syurbasi, Sejarah dan Biografi Empat Imam Mazhab, (Jakarta: Amzah, 2001), 137.

${ }^{39}$ Ahmad Asy-Syurbasi, Sejarah dan Biografi Empat Imam Mazhab, ((Jakarta: Amzah, 2001), 190.

${ }^{40}$ Kamil Muhammad 'Uwaidah, Ahmad ibn Hanbal Imam Ahl as-Sunnah wa al- Jama'ah, (Beirut: Dar al-Kutub al-'Ilmiyyah, 1413H/ 1992M), 3.

${ }^{41}$ Moenawir Chalil, Biografi Empat Serangkai Imam Mazhab Hanafi, Maliki, Syafi'I, Hambali, (Jakarta: Bulan Bintang, 1955), 251. 


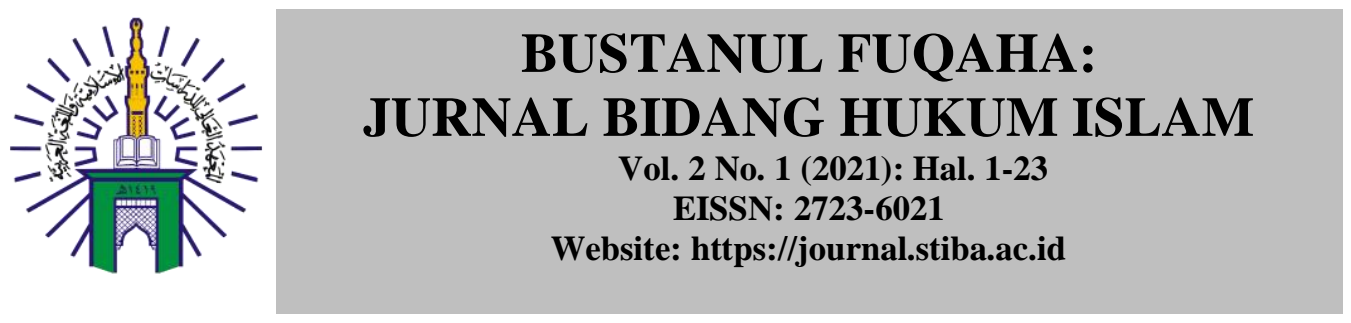

pulak beliau tidak tamak pada harta orang lain ${ }^{42}$.

Sejak masa kecil Imam Ahmad yang fakir dan yatim itu telah dikenal sebagai orang yang sangat mencintai ilmu. Baghdad dengan segala kepesatannya dalam pembangunan termasuk kepesatan dalam perkembangan ilmu pengetahuan membuat kecintaan beliau terhadap ilmu bersambut dengan baik. Beliau mulai belajar ilmu-ilmu keislaman seperti Al-Qur'an, hadis, bahasa Arab dan sebagainya kepada ulama-ulama yang ada di Baghdad. Kefakiran Imam Ahmad membatasi cita-citanya untuk menuntut ilmu lebih jauh. Karena itu beliau tidak segan mengerjakan pekerjaan apapun untuk mendapatkan uang selama pekerjaan itu baik dan halal. Beliau pernah membuat dan menjual baju, menulis, memungut gandum sisa panen dan pengangkut barang.

Pada masa pemerintahan Harun ar-Rasyd yaitu pada umur 16 tahun Imam Ahmad mulai mempelajari hadis secara khusus. Orang yang pertama kali didatangi untuk belajar hadis adalah Hasyim bin Basyir bin Khazin al-Wasiti. Tekadnya untuk menuntut ilmu dan menghimpun hadis mendorongnya untuk mengembara ke pusat-pusat ilmu keislaman seperti Basrah, Hijaz, Yaman, Makkah, dan Kufah. Bahkan beliau telah pergi ke Basrah dan Hijaz masing- masing sebanyak lima kali. Dalam pengembaraan tersebut, beliau bertemu dengan beberapa ulama besar seperti 'Abd ar-Razzaq bin Humam, 'Ali bin Mujahid, Jarir bin 'Abd al-Hamid, Sufyan bin 'Uyainah, Abu Yusuf Ya'kub bin Ibrahim al-Ansari (murid Imam Abu Hanifah), Imam Syafi'i dan lain-lain. Pertemuannya dengan Imam Syafi'i itulah beliau mempelajari fikih, ushul fikih, nasikh dan mansukh serta kesahihan hadis ${ }^{43}$.

Perhatiannya terhadap hadis membuahkan kajian yang memuaskan dan memberi warna lain pada pandangan fikihnya. Beliau lebih banyak mempergunakan hadis sebagai rujukan dalam memberi fatwa-fatwa fikihnya. Karya beliau yang paling terkenal adalah al-Musnad, didalamnya terhimpun 40.000 buah hadis yang merupakan seleksi dari 70.000 hadis. Ada yang berpendapat bahwa seluruh hadist dalam kitab tersebut adalah shahih. Sebagian lainnya mengatakan bahwa di dalamnya terdapat beberapa hadis $d a$ 'if (lemah). Sebagai ulama besar Imam Ahmad tidak luput dari berbagai cobaan. Cobaan terbesar yang dialaminya adalah pada masa pemerintahan al-Ma'mun, al- Mu'tasim, dan al-Wasiq. Pada masa itulah aliran Muktazilah mendapat sukses besar karena menjadi mazhab resmi negara. Para tokoh Muktazilah menghembuskan isu yang tidak bertanggung jawab yaitu terjadinya peristiwa Khalq al-Qur'an (pemakhlukan terhadap Al-Qur'an). Khalifah al-Ma'mun mempergunakan kekuasaannya untuk memaksa para ulama ahli fikih dan ahli hadis agar mengakui bahwa Al-Qur'an adalah makhluk. Peristiwa inilah yang kemudian dikenal dengan peristiwa mihnah. Dengan demikian,

42 T.M Hasbi Ash-Shidieqqy, Pokok-pokok Pegangan Imam-Imam Mazhab dalam Membina Hukum Islam, (Cet. 2; Jakarta: Bulan Bintang, 1974), 268.

${ }^{43}$ Abdullah ibn 'Abd al-Muhsin at-Turki, Usul Mazhab al-Imam Ahmad, (Riyad: Maktabah ar-Riyad al-Hadisah, 1980), 33-34. 


\section{BUSTANUL FUQAHA:

berawal dari sinilah titik awal berkembangnya Mazhab Hanbali yang dilatari oleh dialektika perkembangan ilmu pengetahuan (dirasah Islamiyah), perselisihan teologis, dan kondisi politik, sehingga berdampak pada pula pada pandangan usul fiqh dan fikih beliau $^{44}$.

Banyak di antara mereka yang membenarkan paham al-Ma'mun lantaran ketakutan. Namun demikian, Imam Ahmad dan beberapa ulama lain tetap menolak paham tersebut. Beliau berpendapat bahwa Al-Qur'an bukanlah makhluk tetapi kalam Allah (perkataan Allah). Tidak sedikit ulama yang dianiaya lantaran bersebrangan dengan penguasa, tak terkecuali Imam Ahmad. Beliau lebih memilih dicambuk dan dipenjara dari pada harus mengakui bahwa Al-Qur'an adalah makhluk. Beberapa bulan kemudian alMa'mun mangkat namun sebelumnya ia sempat berwasiat kepada calon penggantinya yaitu al-Mu'tasim agar melanjutkan kebijakannya. Dengan demikian, Imam Ahmad dan beberapa kawannya tetap dipenjara dan disiksa sampai pemerintahan al-Ma'tasim berakhir. Sepeninggalan al-Mu'tasim roda pemerintahan dipegang oleh putranya yaitu alWasiq. Pada masa ini pula kebijakan ayahnya tetap dipertahankan sehingga Imam Ahmad dan beberapa ulama lain yang sependirian dengan beliau tetap juga dipenjarakan dan disiksa. Sampai akhirnya al-Wasiq pun mangkat. Demikianlah Imam Ahmad bertahuntahun meringkuk dalam penjara dan menangggung sengsara lantaran dicambuk dengan cemeti sedang tangannya diikat, yaitu sejak al-Ma'mun menjabat sebagai kepala negara sampai pada zaman al-Wasiq. Setelah al-Wasiq mangkat jabatan kepala negara dipegang oleh al-Mutawakkil. Pada masa inilah segala bidah dalam urusan agama dihapuskan dan menghidupakan kembali sunah Nabi saw. Oleh karena itu, dengan sendirinya masalah Khalq Al-Qur'an sudah tidak ada. Dengan demikian, Imam Ahmad dan beberapa kawannya dibebaskan dari penjara. Sebaliknya para ulama yang menjadi sumber fitnah tentang masalah kemakhlukan Al-Qur'an ditangkap serta dipenjara serta dijatuhi hukuman dera oleh al-Mutawakkil. Para tokoh muktazilah mendapat tekanan hebat lantaran mendapat penyiksaan seperti yang pernah mereka lakukan terhadap para ulama yang menentang pendapatnya ${ }^{45}$.

Guru-gurunya yang mengarahkan pandangan Imam Ahmad ialah Husen bin Bashir bin Abi Hazim lahir pada tahun $104 \mathrm{H}$, wafat pada tahun $183 \mathrm{H}$. Inilah guru Imam Ahmad yang pertama dan utama dalam bidang hadis. Lima tahun lamanya Imam Ahmad ditempa oleh Husen ini. Beliau boleh dikatakan adalah sosok yang banyak mempengaruhi kehidupan Imam Ahmad. Untuk mendalami cara istinbat dan membina fikih, Imam Ahmad berguru kepada Imam as-Syāfi'i. Padanya dipelajari fikih dan ushul. Imam Ahmad terpilih hatinya kepada kecakapan Imam as-Syāfi'i dalam beristinbat.

\footnotetext{
${ }^{44}$ Rahmat Abd. Rahman, "Latar Belakang Sosial Lahirnya Mazhab Hambali." BUSTANUL FUQAHA: Jurnal Bidang Hukum Islam 1.3 (2020): 505-504

${ }^{45}$ Moenawir Chalil, Biografi Empat Serangkai Imam Mazhab Hanafi, Maliki, Syafi'I, Hambali, (Jakarta: Bulan Bintang, 1955), 279-281.
} 


\section{BUSTANUL FUQAHA: \\ JURNAL BIDANG HUKUM ISLAM \\ Vol. 2 No. 1 (2021): Hal. 1-23 \\ EISSN: 2723-6021 \\ Website: https://journal.stiba.ac.id}

Imam Syāfi'i lah yang mengarahkannya kepada istinbat itu, Imam Syāfi'i adalah guru yang kedua bagi Imam Ahmad. Selain dari pada guru besar ini, banyak pula ulamaulama lain yang memberikan pelajaran kepada Imam Ahmad. Tidak kurang dari 100 orang ulama besar yang memberikan pelajaran kepadanya, baik yang di Baghdad maupun di kota-kota lain.

Adapun di antara guru-guru Imam Ahmad bin Hanbal adalah: Imam Isma'il bin Aliyyah, Hasyim bin Basyir, Hammad bin khalil, Mansyur bin Salamah, Mudlaffar bin mudrik, Utsman bin Umar, Masyim bin Qashim, Abu Said Maula Bani Hasyim, Muhammad bin Yazid, Muhammad bin 'Ady, Yazid bin Harun, Muhammad bin Jaffar, Ghundur, Yahya bin Said al-Cathan, Abdurrahman bin Mahdi, Basyar bin al-Fadhal, Muhammad bin Bakar, Abu Daud ath-Thayalisi, Ruh bin 'Ubaidah, Wakil bin al-Jarrah, Mu'awiyah al-Aziz, Abdullah bin Muwaimir, Abu Usamah, Sufyan bin Uyainah, Yahya bin Salim, Muhammad bin Syafi'i, Ibrahim bin Said, Abdurrazaq bin Humam, Musa bin Thariq, Walid bin Muslim, Abu Masar al-Dimasyqy, Ibnu Yaman, Mu'tamar bin Sulaiman, Yahya bin Zaidah dan Abu Yusuf al-Qadi. Guru-guru Imam Ahmad bin Hanbal yang terkenal itu terdiri dari ahli Fikih, ahli Ushul, ahli Kalam, ahli Tafsir, ahli Hadis, ahli Tarikh dan ahli Lughah $^{46}$.

\section{Kekuatan Istidlal Jumhur Ulama}

Istilah jumhur mungkin termasuk sebuah istilah yang sering kita dengar atau kita baca, terkhusus dalam masalah fikih. Memang benar, pendapat jumhur ulama bukan dalil dan tidak pasti benar. Namun, pendapat mereka secara umum atau mayoritas di atas kebenaran, sehingga dapat dijadikan indikasi dan penguat untuk suatu pendapat. Oleh karena itu, hampir tidak didapatkan suatu pendapat jumhur, kecuali dalil bersama mereka dalam masalah tersebut baik secara langsung atau tidak langsung. Walaupun sepintas kelihatannya lemah dan tidak memiliki dalil, namun jika diteliti dengan cermat, maka tidak demikian adanya. Dalam merajihkan (menguatkan suatu pendapat) dengan menggunakan indikasi penguat dengan pendapat jumhur, juga merupakan amaliah para ulama salaf. Imam An-Nawawi dalam kitabnya Al-Majmū Syarhu Al-Muhazab berkata: "Imam As-Sāyifi'i berkata: Aku berhujah/berdalil dengan mursal tabiin senior apabila diisnadkan (diriwayatkan) dari jalur lain, atau dimursalkan oleh seorang rawi dari selain jalur yang pertama dari orang-orang yang diambil ilmunya, atau mencocoki pendapat sebagian sahabat, atau isinya telah difatwakan oleh mayoritas" ${ }^{\prime 4}$.

Imam Ibnu Qudamah berkata dalam kitabnya Al-Mugni: "Maka apa yang telah kami sebutkan bersamaan dengan adanya kesesuaian dengan berbagai hadits dan

${ }^{46}$ T.M Hasbi Ash-Shidieqqy, Pokok-pokok Pegangan Imam-Imam Mazhab dalam Membina Hukum Islam (Jakarta: Bulan Bintang, 1968), 273-275.

${ }^{47}$ Abu Zakaria Muhyi Ad-Dīn Bin Syaraf An-Nawawi, Al-Majmū Syarhu Al-Muhazab (t.t. Dār AlFikr, t.th.), 103. 


\section{BUSTANUL FUQAHA: \\ JURNAL BIDANG HUKUM ISLAM \\ Vol. 2 No. 1 (2021): Hal. 1-23 \\ EISSN: 2723-6021 \\ Website: https://journal.stiba.ac.id}

(kesesuaian) dengan pendapat mayoritas ulama lebih utama"48. Oleh karena itu, dari penjelasan di atas bahwasanya para ulama salaf adalah orang-orang yang sangat hati-hati sekali untuk menyelisihi pendapat jumhur. Mereka tidak akan menyelisihinya, sampai benar-benar nyata kebenaran bagi mereka. Bahkan amaliah dan ciri khas mereka justru senantiasa mengikuti pendapat jumhur ulama. Dalam menetapkan suatu hukum para ulama memiliki masing-masing metode dalam penetapannya, dan hukum yang penulis maksud disini adalah sebuah perbuatan yang belum ada hukumnya di dalam Al-Qur'an, hadis dan ijmak ulama. Hal ini dikarenakan ulama berbeda-beda dalam penetapan hukumnya, maka penulis akan menyebutkan satu persatu metode pengambilan hukum. Adapun metode pengambilan hukum Imam Malik yaitu: Al-Qur'an, sunah, ijmak, perbuatan orang Madinah, perkataan sahabat, Kias, Al-Maslahah Al-Mursalah (masalahmasalah yang belum ada di dalam Al-Qur'an dan hadis), Saddu Az-Zarai' (mencegah sesuatu perbuatan agar tidak sampai menimbulkan kerusakan), $A l$ - 'Urf (kebiasaan) $)^{49}$.

Selanjutnya, metode pengambilan hukum Imam As-Syāfi'I meliputi: Al-Qur'an, sunah kecuali hadis mursal, ijmak, kias, perkataan sahabat, dan Al-urf (kebiasaan) ${ }^{5051}$. Adapun metode pengambilan hukum Imam Ahmad meliputi: An-Nash (yaitu Al-Qur'an dan hadis), ijmak, fatwa sahabat, perkataan sahabat, hadis mursal, kias, Al-'Urf

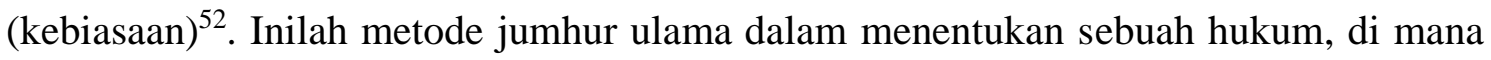
mereka akan merujuk kepada Al-Qur'an, sunah dan lain-lain, jika mereka ingin mengetahui suatu hukum yang belum ada hukumnya atau sebuah perbuatan yang baru saja terjadi (kontemporer).

\section{Nikah Dengan Lafaz Hibah Perspektif Jumhur dan Imam Abu Hanifah Pengertian Nikah dengan Lafaz Hibah}

Lafaz adalah suatu ucapan atau perkataan yang keluar dari lisan seseorang yang terdiri dari satu kalimat atau lebih, sedangkan pengertian lafaz nikah yang sering disebut dengan akad nikah di dalam kompilasi hukum Islam di Indonesia yaitu, rangkaian ijab yang diucapkan oleh mempelai pria atau wakilnya disaksikan dua orang saksi. Nikah dengan lafaz hibah adalah pernikahan di mana sebuah ijab kabul yang menggunakan sigat hibah atau alih kepemilikan dari seorang ayah atau wali sang mempelai wanita kepada sang mempelai pria, contohnya seperti perkataan sang wali kepada sang mempelai pria

48 Syamsudin Muhammad Bin Ahmad Al-khotīb As-Syarbini As-Syāfi'i, Mugni Al-Muhtāj ilā Ma'rifati Mā̄'ni Al-fāz Al-Minhāj (Cet. 1; t.t. Dār Al-Kutub Al-Ilmiyah, 1415 H/ 1994 M), 613.

49 Abdullah Bin Abdul Muhsin Al-Toriqi, Khulașațu Tārīkh At-Tasyrī', (t.t. Dār al-Nasyr: Mu'assasah al-Juraisī lī al-Tauzī' $\left.{ }^{\prime}, 2011\right), 84-85$.

50 Abdullah Bin Abdul Muhsin Al-Toriqi, Khulașațu Tārīkh At-Tasyrī', (t.t. Dār al-Nasyr: Mu'assasah al-Juraisī lī al-Tauzī', 2011), 86-87.

${ }^{51}$ Muhammad Taufan Djafry, Muhammad Taufan. "Metode Ijtihad Imam al-Syafi'i dalam Kitab al-Risalah." NUKHBATUL'ULUM: Jurnal Bidang Kajian Islam 2.1 (2016): 193.

52 Abdullah Bin Abdul Muhsin Al-Toriqi, Khulașaṭu Tārīkh At-Tasyrī', (t.t. Dār al-Nasyr: Mu'assasah al-Juraisī lī al-Tauzī’ , 2011), 87-88. 
bahwasanya: "Saya hibahkan anak saya kepada Anda dengan mahar yang telah ditentukan tunai karna Allah swt." Tetapi kebanyakan orang tidak menggunakan lafaz ini karena yang lebih terkenal dikalangan masyarakat adalah penggunaan sigat atau lafaz al-nikah dan lafaz al-tazwij, jadi penggunaan lafaz ini menjadi sebuah perbedaan dikalangan para ulama, ada yang mengatakan penggunaan lafaz nikah hanya dengan sigat al-nikah dan altazwij dan ada yang mengatakan boleh juga dengan menggunakan lafaz hibah.

\section{Pendapat Jumhur Ulama terhadap Nikah dengan Lafaz Hibah}

Sebelum membahas pendapat jumhur terhadap nikah dengan lafaz hibah maka kita harus mengetahui siapa itu jumhur ulama, adapun jumhur ulama yang dimaksud oleh penulis disini adalah sebagaimana yang telah dijelaskan sebelumya bahwasanya jumhur ulama adalah tiga ulama mazhab dari pendiri mazhab yang terkenal di antaranya: Imam Malik, Imam Syafi'I dan Imam Ahmad. Berikut pendapat para ulama tentang nikah dengan lafaz hibah.

Jumhur ulama tidak ada menyebutkan dalam kitab-kitabnya pelarangan yang jelas bahwa tidak bolehnya menggunakan lafaz hibah dalam melangsungkan akad nikah, namun jumhur ulama hanya menyebutkan penggunaan lafaz dalam akad nikah hanyalah penggunaan lafaz al-nikah dan al-tazwij, atau biasa yang dikenal dengan saya nikahkan dan saya kawinkan. Imam As-Syarbini salah satu murid dari imam As-Syāfi'I menyebutkan dalam kitabnya Mugni Al-Muhtāj ilā Ma'rifati Mā̄'ni Al-fāz Al-Minhāj: Sesungguhnya nikah itu sah hanya dengan ijab yaitu (saya nikahkan atau saya kawinkan) anak saya dan seterusnya misalkan dan kabul yaitu dengan perkataan suami saya terima nikahnya atau saya terima kawinnyn dan seterusnya ${ }^{53}$. Imam An-Nawawi juga menuliskan didalam bukunya Al-Majmū Syarhu Al-Muhzab, berbunyi: "Dan tidak sah sebuah akad kecuali dengan lafaz al-tazwij dan al-nikah, karena selain dari keduanya dari lafaz alih kepemilikan dan hibah belum termasuk kedalam makna nikah"54.

Dari kutipan di atas menjelaskan bahwa Imam As-Syāfi'i hanya membolehkan lafaz al-tazwij dan al-nikah dalam pelaksanaan akad nikah dan selain dari kedua lafaz tersebut maka tidak sah sebuah akad nikah. Kemudian Imam Ibnu Qudamah yang merupakan salah satu ulama fikih mazhab Al-Hanabilah menuliskan dalam bukumya Al-Mugni, berbunyi: "Dan tidak sah pernikahan jika tidak menggunakam lafaz al-nikah dan al-tazwij" syarat-syarat nikah adalah ijab dan kabul, dan tidak sah sebuah ijab dan kabul jika tidak

53 As-Syāfí'I, Syamsudin Muhammad Bin Ahmad Al-khotīb As-Syarbini, Mugni Al-Muhtāj ilā Ma'rifati Maā'ni Al-fāz Al-Minhāj (Cet. 1; t.t. Dār Al-Kutub Al-Ilmiyah, 1415 H/ 1994 M), 226.

${ }^{54}$ Abu Zakaria Muhyi Ad-Dīn Bin Syaraf An-Nawawi, Al-Majmū Syarhu Al-Muhaẓab, (Beirut: Dar al Fikr, t.t), 209.

55 Abu Muhammad Muwafiq Ad-Dịn Abdullah Bin Ahmad Bin Muhammad Qudāmah AlJamāī'lī Al-Muqadasi Al-Damasqi Al-Hanbali, Al-Syahīr Bi Ibn Qudāmah Al-Muqadasi, Al-Mugni (t.t. Maktabah Al-Qāhirah, 1388 H/ 1968 M), 78. 
menggunakan kata al-nikah atau al-tazwij, seperti saya nikahkan engkau dengan anak saya, karena selain dari itu tidak termasuk dalam makna nikah, maka akad tidak sah" ${ }^{\text {"56. }}$.

Inilah beberapa pendapat ulama yang terdapat pada buku-buku mereka yang mengatakan bahwa selain penggunaan lafaz al-nikah atau al-tazwij maka penikahan atau akad yang tidak sah.

\section{Pendapat Imam Abu Hanifah terhadap Nikah dengan Lafaz Hibah}

Imam Abu Hanifah adalah Imam yang berpendapat bahwa sebuah lafaz selain dari lafaz al-nikah atau al-tazwij seperti lafaz hibah boleh dalam akad pernikahan, karena selagi masih merupakan bentuk alih kepemilikan, maka itu boleh untuk dilakukan. Imam As-Sarkhasi mengatakan dalam buku Al-Mabsut bahwasanya nikah dengan lafaz hibah, dibolehkan dan nikah dengan lafaz hibah, merupakan sedekah dan alih kepemilikan yang dibenarkan dalam perkataan ulama kita ${ }^{57}$. Imam Al-Kasani juga menyebutkan dalam bukunya Badāi' As-Sonai fi Tartib As-Syaroi, menyebutkan tidak ada perbedaan bahwasanya nikah dengan lafaz al-nikah atau al-tazwij, akan tetapi apakah sah dengan menggunakan lafaz jual beli, hibah, sedekah dan alih kepemilikan? Ulama kita berkata hukumnya $\operatorname{sah}^{58}$.

\section{Analisis Istinbat Hukum Jumhur Ulama dan Imam Abu Hanifah Mengenai Nikah Dengan Lafaz Hibah}

Mengenai metode istinbat jumhur ulama dan Imam Abu Hanifah dalam hal nikah dengan lafaz hibah, para ulama berbeda pendapat dalam menafsirkan ayat dalam AlQur'an, firman Allah Ta'ala dalam Qs. Al-Ahzab/33:50. Al-Hanafiyah atau Mazhab Imam Abu Hanifah berdalil dengan ayat ini bahwasanya nikah dengan lafaz hibah boleh, dengan berdalilkan dalam ayat ini bahwasanya Allah swt. menamai akad nikah dengan lafaz hibah sebagai sebuah pernikahan kepada nabi, dan ketika nabi boleh menggunakannya maka hal tersebut juga boleh dilakukan oleh umatnya karena umat Nabi Muhammad saw. dianjurkan untuk selalu mengikuti dan mencontohi nabi. Al-Hanafiyah juga berkata bahwasanya nabi dan umatnya dalam hal lafaz nikah adalah sama, dan penghususan yang telah diisyaratkan dalam ayat tersebut adalah bolehnya Nabi Muhammad saw. menikah tanpa mahar, dengan berdalilkan firman Allah Ta'ala dalam akhiran ayat tersebut yang notabanenya berupa penghususan untuk mengangkat keberatan atau kesulitan, dan kesulitan dalam hal ini adalah untuk menyediakan mahar,

\footnotetext{
${ }^{56}$ Abu Muhammad Muwafiq Ad-Dịn Abdullah Bin Ahmad Bin Muhammad Qudāmah Al-Jamāì'lī Al-Muqadasi Al-Damasqi Al-Hanbali, Al-Syahīr Bi Ibn Qudāmah Al-Muqadasi, Al-Kāfī Fī Fiqhi Imām Ahmad, (Cet. 1; t.t. Dār Al-Kutub Al-Ilmiyah, 1414 H/ 1994 M), 20.

${ }^{57}$ Muhammad Bin Ahmad Bin Abi Sahli Syamsu Al-Aimmah Al-Sarkhasi, Al-Mabsut ( Bairut: Dār Al-Ma'rifah, 1414H/ 1993 M), 59.

${ }^{58}$ I'lā Ad-Dīn Abu Bakar Bin Masu'd Bin Ahmad Al-Kasani Al-hanafi, Badāi' As-Sonai fi Tartib As-Syaroi ( Cet. 2; t.t. Dār Al-Kutub Al-Ilmiyah, 1406 H/ 1986 M), 229.
} 


\section{BUSTANUL FUQAHA: \\ JURNAL BIDANG HUKUM ISLAM \\ Vol. 2 No. 1 (2021): Hal. 1-23 \\ EISSN: 2723-6021 \\ Website: https://journal.stiba.ac.id}

maka demi untuk tidak membebani nabi maka dibolehkan baginya untuk menikah tanpa mahar. Adapun jumhur ulama mereka mengatakan bahwasanya penggunaan lafaz hibah dalam akad nikah tidak dibolehkan, karena dalam ayat ini, Allah swt. mengkhususkan kepada rasulnya yaitu bolehnya menikah menggunakan lafaz hibah tanpa mahar dengan berdalilkan ayat di atas, dan apapun yang telah menjadi kekhususan nabi maka tidak boleh satupun dari umatnya untuk mengikutinya ${ }^{59}$.

\section{KESIMPULAN}

Berdasarkan pada kajian yang dilakukan oleh penulis, maka dapat diambil kesimpulan bahwa nikah dengan lafaz hibah tidak dianjurkan menurut jumhur ulama karena jumhur ulama hanya membolehkan lafaz nikah dengan lafaz al-nikāh dan altazwij sebagaimana biasanya. Sebaliknya, nikah dengan lafaz hibah boleh dalam mazhab Imam Abu Hanifah karena selagi hal tersebut masih dalam bentuk alih kepemilikan maka lafaz tersebut boleh digunakan dalam pelaksanaan akad nikah.

Kajian ini berupa studi komparatif, yaitu studi yang membandingkan satu pendapat dengan pendapat lainya, dalam hal ini pendapat jumhur ulama dengan Imam Abu Hanifah tentang nikah dengan lafaz hibah. Setelah proses pengkajian, ditemukan bahwasanya salah satu pendapat jumhur ulama mengatakan bahwa nikah atau lafaz nikah hanya boleh menggunakan lafaz al-nikah dan al-tazwij, dan selain dari kedua itu maka tidak diperbolehkan. Jadi, penggunaan lafaz hibah dalam sebuah akad pernikahan tidak diperbolehkan dalam pandangan jumhur ulama, namun tidak mengapa bagi siapa saja yang ingin menggunakan pendapat Imam Abu Hanifah tentang bolehnya menggunakan lafaz hibah dalam sebuah akad pernikahan, karena hal ini hanyalah sebuah perbedaan dalam masalah fikih yang terkadang para ulama berbeda dalam menafsirkan atau memahami sebuah dalil.

Dengan demikian, hal tersebut menunjukkan bahwa penggunaan lafaz hibah dalam akad nikah tampak tidak memadai untuk diterapkan di negara kita, Indonesia, di mana mayoritas penduduk atau kebanyakan masyarakat kita bermazhab As-Syāfi' sehingga lafaz nikah hanya menggunakan lafaz al-nikah dan al-tazwij sebagaimana pendapat jumhur ulama dan sebagaimana yang telah tersebar ditengah-tengah masyarakat Indonesia.

\section{DAFTAR PUSTAKA}

Abu Zaid, Farouq, Hukum Islam antara Tradisional dan Modernis. Jakarta: Perhimpunan Pengembangan Pesantren dan Masyarakat, 1986.

Al-Bukhārī, Muḥammad bin Ismā̄îl bin Ibrāhīm bin al-Mugīrah. Șaḥịh al-Adab alMufrad lì al-Imām al-Bukhārī, Cet. IV, t.t.: Dār al-Șadīq lī al-Nasyr wa al-Tauzī',

${ }^{59}$ Muhammad Ali As-Sābuni, Rowāi' Al-Bayān Tafsīr Āyātu Al-Ahkām, (Cet. 3; t.t. Maktab AlGhazali, 1400 H/ 1980 M), 309-311. 


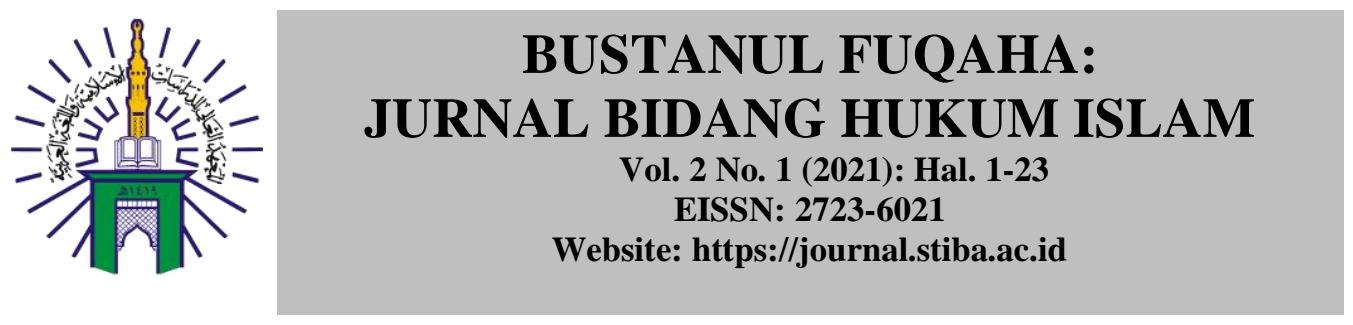

1997.

Al-Andalusy, Abi Al-Walīd Muhammad Bin Ahmad Bin Muhammad Bin Ahmad Bin Rusyd Al-Qurțobi, Bidāyatul Mujtahid Wa Kifāyatul Muqtașid, t.t Dār Al-Hadis, $2004 \mathrm{M} / 1425 \mathrm{H}$.

Al-Hanafi, I'lā Ad-Dīn Abu Bakar Bin Masu'd Bin Ahmad Al-Kasani. Badāi' As- Sonai fi Tartib As-Syaroi'. Cet. 2; t.t. Dār Al-Kutub Al-Ilmiyah, 1986 M/1406 H.

Al-Hanbaly, Mansur bin Yunus bin Sholahuddin bin Hasan bin Idris Al-Bahuty, Qisyaf Al-Qona' An Matan Al-Iqna'. t.t. Dār Al-Kutub Al-Ilmiyah, t.th.

Al-Muqadasi, Abu Muhammad Muwafiq Ad-Dịn Abdullah Bin Ahmad Bin Muhammad Qudāmah Al-Jamā̄̄’̀̄̄ Al-Muqadasi Al-Damasqi Al-Hanbali, AlSyahīr Bi Ibn Qudāmah. Al-Kāfî F̄̄ Fiqhi Imām Ahmad . Cet. 1; t.t. Dār Al-Kutub Al-Ilmiyah, $1994 \mathrm{M} / 1414 \mathrm{H}$.

Al-Muqadasi, Abu Muhammad Muwafiq Ad-Din Abdullah Bin Ahmad Bin Muhammad Qudāmah Al-Jamā̄̄'l̄̄ Al-Muqadasi Al-Damasqi Al-Hanbali, AlSyahīr Bi Ibn Qudāmah. Al-Mugni. t.t. Maktabah Al-Qāhirah, 1968 M/1388 H.

Al-Ramli, Muhammad bin Ahmad, Ghoyah Al-Bayan Syarah Zubad Ibn Ruslan. Beirut: Dar Al-Kutub Al-Islamiyah, 2012.

Al-Sarkhasi, Muhammad Bin Ahmad Bin Abi Sahli Syamsu Al-Aimmah. Al-Mabsut. Bairut: Dār Al-Ma'rifah, 1993 M/1414H.

Al-Toriqi, Abdullah Bin Abdul Muhsin. Khulașațu Tārīkh At-Tasyrī'. t.t. Dār al-Nasyr:

Mu'assasah al-Jurais̄̄ lī al-Tauzī, 2011.

Al-Turki, Abdullah ibn 'Abd al-Muhsin. Usul Mazhab al-Imam Ahmad. Riyad: Maktabah ar-Riyad al-Hadisah, 1980 M/1400 H.

Al-Zuhaily, Wahbah Bin Musțofa, Al-Fiqhu Al-Islāmy Wa Adillatuhu (cet ke-4, Beirut: Dar al-Firk, 1997, 3260

An-Nawawi, Abu Zakaria Muhyi Ad-Dīn Bin Syaraf. Al-Majmū Syarhu Al-Muhaẓab.

t.t. Dār Al-Fikr, t.th.

As-Sābuni, Muhammad Ali, Rowāi' Al-Bayān Tafsīr Āyātu Al-Ahkām, Cet. 3; t.t. Maktab Al- Ghazali, 1980 M/ 1400 H.

As-Syāfi'I, Syamsudin Muhammad Bin Ahmad Al-khotīb As-Syarbini, Mugni AlMuhtāj ilā Ma'rifati Maā’ni Al-fāz Al-Minhāj, Cet. 1; t.t. Dār Al-Kutub AlIlmiyah, $1994 \mathrm{M} / 1415 \mathrm{H}$.

Asy-Syurbasi, Ahmad. Sejarah dan Biografi Empat Imam Mazhab. Jakarta: Amzah, 2001.

Ash-Shidieqqy, T.M Hasbi, Pokok-pokok Pegangan Imam-Imam Mazhab dalam Membina Hukum Islam, Cet. 2. Jakarta: Bulan Bintang, 1974

Bastoni, Hendri Andi, 101 Kisah Tabi'in, Cet. 1. Jakarta: Pustaka al-Kausar, 2006

Chalil, Moenawir. Biografi Empat Serangkai Imam Mazhab Hanafi, Maliki, Syafi'i,. Hambali. Jakarta: Bulan Bintang, 1955.

Djafry, Muhammad Taufan. "Metode Ijtihad Imam al-Syafi'i dalam Kitab alRisalah." NUKHBATUL'ULUM: Jurnal Bidang Kajian Islam 2.1 (2016): 185194. 


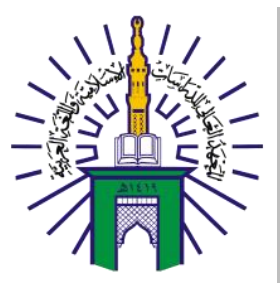

\section{BUSTANUL FUQAHA: \\ JURNAL BIDANG HUKUM ISLAM \\ Vol. 2 No. 1 (2021): Hal. 1-23 \\ EISSN: 2723-6021 \\ Website: https://journal.stiba.ac.id}

Farid, Syaikh Ahmad, Min A'lam As-Salaf, Trans. Masturi Ilham, Asmu'i Taman. Jakarta: Pustaka Kautsar, 2007.

Hajar M, Model-Model Pendekatan Dalam Penelitian Hukum dan Fiqh Cet I. Yogyakarta: Kalimedia, 2017.

KBBI Daring, Jumhur, https://kbbi.kemdikbud.go.id/entri/jumhur.

Kementrian Agama RI, Al-Qur'an dan Terjemahnya.

Khalil, Rasyad Hasan, Tarikh Tasyri', Sejarah Legislasi Hukum Islam. Jakarta: Amzah, 2009

Majmūatun minal muallifīn, Al-Fiqhu Al-Muyassar Fii Daui Al-Kitab Wa As-Sunnah

(Cet. I; t.t. Majma`Malik Fahd Li Thibaah Mushaf Syarif, 2003 M/ 1424 H

Muḥammad bin Ismā'̄il Abū 'Abdillāh al-Bukhārī, (al-Muḥaqqiq: Muḥammad Zuhaīr bin Nāṣir al-Nāṣir), Șaḥīḥ al-Bukhārī jilid 3. Cet I; t.t.: dār țauq al-Najāh, 2001.

Pranata, Wiwin, and Abdul Rahim. "Penundaan Kehadiran Anak Akibat Perkawinan Usia Muda Ditinjau Menurut Hukum Islam (Studi pada Desa Jaling, Kecamatan Awangpone, Kabupaten. Bone)." NUKHBATUL'ULUM: Jurnal Bidang Kajian Islam 4.2 (2018): 173-179.

Rahman, Rahmat Abd. "Latar Belakang Sosial Lahirnya Mazhab Hambali." BUSTANUL FUQAHA: Jurnal Bidang Hukum Islam 1.3 (2020): 505515.

Soekanto, Soejono dan Sri Mamudji. Penelitian Hukum Normatif: Suatu Tinjauan Singkat. Jakarta: Rajawali Pers, 2001

Syamhudi, Kholid. "Hibah dalam perspektif fikih.", last modified Februari 08, 2021, https://almanhaj.or.id/6422-hibah-dalam- perspektif-fikih.html

Undang-undang Republik Indonesia, Nomor 1 Tahun 1974, Tentang Perkawinan. Bandung: Citra Umbara, 2007.

'Uwaidah, Kamil Muhammad, Ahmad ibn Hanbal Imam Ahl as-Sunnah wa al- Jama'ah, Beirut: Dar al-Kutub al-'Ilmiyyah, 1992 M/ 1413 H. 